Sign Systems Studies 30.1, 2002

\title{
Feeling the signs: The origins of meaning in the biological philosophy of Susanne K. Langer and Hans Jonas
}

\author{
Andreas Weber \\ Institute for Cultural Studies, Humboldt-Universität zu Berlin \\ Sophienstraße 22a, D-10178 Berlin, Germany ${ }^{1}$ \\ e-mail: andreas.weber@rz.hu-berlin.de
}

\begin{abstract}
This paper describes the semiotic approach to organism in two proto-biosemiotic thinkers, Susanne K. Langer and Hans Jonas. Both authors develop ideas that have become central terms of biosemiotics: the organism as subject, the realisation of the living as a closed circular self, the value concept, and, in the case of Langer, the concept of symbol. Langer tries to develop a theory of cultural symbolism based on a theory of organism as a self-realising entity creating meaning and value. This paper deals mainly with what both authors independently call "feeling". Both authors describe "feeling" as a value-based perspective, established as a result of the active self interest manifested by an organic system. The findings of Jonas and Langer show the generation of a subject pole, or biosemiotic agent, under a more precise accent, as e.g. Uexküll does. Their ideas can also be affiliated to the interpretation of autopoiesis given by the late Francisco Varela (embodied cognition or "enactivism"). A synthesis of these positions might lead to insights how symbolic expression arises from biological conditions of living.
\end{abstract}

Art is the surest affidavit that feeling, despite its absolute privacy, repeats itself in each individual life. It is not surprising that this is so, for the organic events which culminate in being felt are largely the same in all of us, at least in their biologically known aspects.

Susanne K. Langer (1967: 64)

\footnotetext{
${ }^{1}$ Private Address: D-21720 Guderhandviertel 90, Germany.
} 


\section{Introduction}

Ideas for a biosemiotic approach to organism, as they have been elaborated in the last ten years or so (Emmeche, Hoffmeyer 1991, Hoffmeyer 1997, Kull 1999), often show affinities to concepts of earlier thinkers, some of them biological "holists". This has best been shown by Sebeok (1976) for the case of Jakob von Uexküll, who by now has become a classic of biosemiotics. My paper is meant as another attempt to discover "proto-biosemiotic" thinking in the 20th century.

Hans Jonas and Suzanne K. Langer have produced influential biophilosophical theories from the 1950s into the 1980s (Langer) viz. the 1990s, Jonas 1973, 1992, Langer 1953, 1967-1982, 1979). Both have developed a range of ideas in their works which touches the theoretical outset of biosemiotics. They (1) conceive of the living as an embodied, material system, they (2) stress its active self realization, they (3) see the living organism as a subject, they (4) conceive of the encounter of this subject with the world as indirect or mediated, hence creating value (in Jonas 1973: 87) words) or vital import (as Langer 1953: 32 puts it). These ideas culminate in Langer into (5) the insight that expressiveness has to be considered as strongly a basic aspect of a living being as functional adaptation (for a review of the differences between Langer und Jonas cf., e.g., Lachmann 2000: 148n64). ${ }^{2}$ The qualities mentioned above for both authors are best characterised by describing the organism as "feeling". ${ }^{3}$ This term, which is somewhat mirrored in other concepts which see the living basically as "desire" (Barbaras 1999) or, in a more technical angle, as "need" (Kull 2000), tries to radically view the living being as a subjective agent, creating meaning from its needs to cope with the surrounding world, with the other. The concepts of "feeling" as Jonas and Langer have elaborated them thus might offer some insights into the subjective dimension created by organic experience.

${ }^{2}$ There is a number of authors who independently developed notions of a protobiosemiotic approach to organism, notably Helmuth Plessner (1928), F. J. Buytendijk (1958), Adolf Portmann (1948, 1960), and Kurt Goldstein (1933, 1934). An oblique affinity also exists with Merleau-Ponty's philosophy. In his Phenomenology of Perception Merleau-Ponty has heavily drawn on the works of Goldstein (Lachmann 2000: 157n12).

${ }^{3}$ The term "feeling" goes back to William James (1890). 
Related ideas can also be found in the version of autopoiesis theory developed by the late Francisco Varela (not identical with the first account of autopoiesis given by Maturana and Varela, 1980). Indeed, although Varela himself always declared that he was not a semiotician, his work touches some important points of biosemiotics. In his late works Varela tried to overcome the solipsistic dangers of early biological constructivism and developed a view of embodied cognition which he called "enactivism". Varela wanted to understand the genesis of selfhood by interactions between autopoietic entities and the external world. In his treatment of the concepts of subjective agency and of biological relevance, and meaning, he prepares ideas which might help a possible synthesis into a "biosemiotic paradigm" (Varela 1991, Varela et al. 1991, Weber, Varela 2002).

\section{Jonas: Feeling and the "mother-value" of all values}

Hans Jonas stems from a phenomenological background. In his attempts to overcome the subject-object dualism (also called the two cultures) of modern science Jonas started to develop a, as he called it, a "biological philosophy". In the centre of his theory of biology stands metabolism. For Jonas, a living system is nothing more than the identity of the process that arranges material compounds into a form. Hence, metabolism is the crucial point of encounter between matter and order, not just energy production. Form arranged by metabolic processes (which in return are the form's structure) is constant, whereas substance, the mere molecules, rather are an accidental agglomeration of matter that may pass through various living forms. For Jonas (1992: 21), an organic

wholeness is self-integrating in active realization, [its] form is not result but cause of the dynamic arrangements of matter, and hence the process at the same time is the form. By this central aspect of its functioning metabolism can very well be considered as defining quality of life: every living being does have it, no entity which is not living does have it. (Jonas 1973: 83) ${ }^{4}$

${ }^{4}$ All translations of Jonas' texts are by the author, as there is no official English translation. Although the work which was published in Germany 1973 as Organismus und Freiheit was a translation from the earlier book "The phenomenon of life" (1966), 


\section{Andreas Weber}

In the architecture of the metabolic process, Jonas sees prevailing a certain tendency to complex systems, a kind of "order for free" (Kauffman 1998). Self-ordering brings forth structure, but also a first duality in the living. As a metabolic process, form becomes in a way autonomous from matter,

[...] the difference between substance and form, which is a pure abstraction when applied to inorganic entities, becomes a real distinction. This implies a complete inversion of the ontological relationship: Form has become an essential quality and substance has become an accidental quality. (Jonas 1973: 125)

Metabolism, and with it the living system as it is, are always open to breakdown. Because the living system is dependent on matter to carry on, its autonomy is restricted to the necessity of incorporating and metabolising pieces of matter. This is what Jonas calls "dependent independence" - a paradox that deeply marks the living, which is on one hand related to itself, on the other to the exterior.

Jonas' description of metabolism reminds of Varela's idea of a circular self-closure. A short look at it may clarify Jonas' position. For autopoiesis theory, the process of the living consists in bringing forth this proper process. Autopoieis, particularly in its reformulation by Varela in the 1990ies, is concerned with the process of creating an autonomous identity (Varela 1991). This identity stands in a dialectical relation to the exterior, or other. The living being is thriving on the other, but also endangered by it. Living is ended not when the compounds are changed, but when the process of automaintenance is disturbed:

An autopoietic system is organized (defined as unity) as a network of processes of production (synthesis and destruction) of components such that these components: (i) continuously regenerate the network that is producing them, and (ii) constitute the system as a distinguishable unity in the domain in which they exist. (Varela 1997: 75)

From this definition, we can better understand the importance of the metabolic model in Jonas' description of the living. The organism is continuously concerned with itself. It tries to keep up metabolic

Jonas had revised the translation and partially rewritten it (Jonas 1973: 3f). Translations of other German sources, if not marked otherwise, are also by the author. 
coherence in the face of changing matter. From this concern, a certain perspective is arising as an interest of the organic system in itself. This establishment of an identity is a basic process of the living. It happens not by revising physical laws for particle-interactions in applying them in a special way to organism, nor by imposing an extramechanical entelechy. The organism creates a subjective pole in its attempt to maintain autonomy over the matter flowing through it. It is structuring matter in the process of self-realization to maintain itself as this very process.

Subjectivity arises as a kind of ontological complement to the material auto-production an organism continuously is concerned with. Subjectivity hence is not just found in human conscious intentionality. It is rather at the ground of any behaviour emerging from the biotic outset. Subjectivity is the expression of the fact that a living system is concerned with itself. Because life is continued existence against the weight of matter there is a subjective perspective emerging in a living system. This is the perspective of concern: a living system is trying to keep itself up against influences and disturbances. Already basic forms of life therefore might have a subjective perspective as a result of their existential need:

The difference between environment and world is the surplus of signification which haunts the understanding of living and of cognition, and which is at the root of how the self becomes one... There is no food significance in sucrose except when a bacterium swims upgradient and its metabolism uses the molecule in a way that allows its identity to continue. This surplus is obviously not indifferent to the regularities and texture (i.e. the 'laws') that operate in the environment, that sucrose can create a gradient and traverse a cell membrane, and so on. On the contrary, the system' s world is build on these regularities, which is what assures that it can maintain its coupling at all times. (Varela 1991: 86, emphasis by the author)

Life is a fragile, precarious principle. Life is not an unlimited successstory, because it is a processual tendency on substantial matter. This permanent instability is the door where the semiotic germ enters the thinking of Jonas: because negation of the living is always possible, its simple existence must always be self-affirmation. Simple existence must be an approvement, a "Yes to myself" to be able to continue. For Jonas, this reflexive movement is the generator of basic value: 
The fundamental point of departure is that life says 'Yes!' to itself. In wishing to continue it declares itself as a value [...] May we thus say that mortality is the narrow door through which value - the thing addressed by 'yes' entered the otherwise indifferent universe? [...] Feeling is the primary condition for something to be 'worth the effort'. Something gains reality only as a given for feeling and as the feeling of that given. The mere presence of feeling, whatever may be its kind, is infinitely superior to it total absence. Thus, the ability to feel as it came about in organism, is the mother value of all values. (Jonas 1992: 87-88)

Jonas here particularly stresses the self reflexive tendency of matter. But he also pays attention to the dependency on an "other", always given and probably as basic and as important, and present in the very core of a biological entity via code-duality of soma and genes, formulated by Hoffmeyer (1997). To understand the organism's necessity to succeed in a surrounding world, Jonas integrates a deep rooted dialectics in his view of living beings: The self-making self has to survive in a world characterised by an "other". In the antinomy of form and matter found in the metabolic principle of life itself this other-reference becomes a first order phenomenon. Hence, and this is most important, Jonas goes radically farther than a cybernetic account oriented at the circular model of the feedback loop. Indeed he criticizes heavily the cybernetic model for its reduction of animal nature to a dyadic structure with perception and motility as the two moving factors,

whereas in reality it is composed of the triad of perception, mobility and feeling. Feeling, more basic than the two other potential, and rather linking them, is the animal translation of the basic tendency, that is at work already from the undifferentiated, pre-animal stage on, in the continuous realization of metabolism. (Jonas 1973: 185-186)

Feeling thus is the interpretant necessary to make up a biosemiotic entity. Feeling that rises from the intrinsic teleology of organism which Jonas is calling here "basic tendency" is the tertium comparationis that links the causa, perception, with its effect, mobility. Such a causality is a teleological, not a mechanical one. (As Varela and Weber, 2002, have argued, the process of the living establishes an intrinsic, or real teleology as a deep feature of the organism). The causation is guided by a self who follows the "mother-value of all 
values" as a final raison d'être, a self which is longing for existence and for further unfolding.

This is what Jonas calls the subject-pole created by the living organism. Feeling always brings forth an interior dimension, or rather, interior, or self, unfold as feeling. What is felt, is felt by this rudimentary "self". What is felt is felt as self, and Self is only possible via feeling. Feeling is the presence of intrinsic teleology, its manifestation as a motivation of behaviour in its most basic sense.

\section{Langer: Feeling and vital import}

Susanne Langer started as a philosopher of logics in Whiteheadian style and then turned to a more holistic viewpoint. Langer has mainly been recognized as a philosopher of art. This judgement certainly does not pay enough justice to her work, particularly in the late volumes of Mind (1967-1982). Langer has worked on a theory of cultural symbols, but she has derived her semiotics from a theory of organism, or, as she called it, "living form".

Langer has become known for her distinction of discursive logical — and presentative symbols. For Langer all symbols are mental concepts. A discursive symbol thus is a conceptual expression of an idea. A presentative symbol, though, is a conceptual expression of lived existence. Langer believes that there is a common ground of experience shared by humans and other organic beings. As "symptoms" (Langer 1953: 25), expressive gestures, postures, colourings and other embodied signs, this lived experience is constantly and spontanously expressed by all organisms, humans and animals alike. A presentative symbol wields the spontaneous embodiment of a symptom into a "felt concept". Presentative concepts hence are integrating biological and cultural semiotics. On the forefront of this semiotics Langer deals with a concept of "feeling".

A presentative symbol for Langer signifies a concept of "felt life", or rather, as she would have it, expresses "felt life". In her eyes, art

5 "Drittens schließt diese Transzendenz Innerlichkeit oder Subjektivität ein, die alle in ihrem Horizont vorkommenden Begegnungen mit der Qualität gefühlter Selbstheit durchtränkt, wie leise ihre Stimme auch sei. Sie muß da sein, damit Befriedigung oder Vereitelung einen Unterschied macht" (1992:26). Jonas (1953) also uses the term 'Emotion'. 


\section{Andreas Weber}

symbols are always presentative symbols, hence are semiotically expressive of feeling. Art reaches farther than the discursive sphere and has its roots in the region of our organic foundations. Art therefore can illustrate organic experience, and vice versa, organic experience can explain certain regularities in art. Both have a common source in a general expressiveness of life. This thesis could not be very popular in the fifties, where Langer was elaborating it in Feeling and Form (1953), but it might lead us to certain insights in organic semioses. In her transition from art semiotics to biosemiotics Langer is guided by the question

what new empirical knowledge of the morphology of feeling can we derive from its image in works of art, and what light can this knowledge throw on the unfelt processes of life and the emergence of feeling, animal mentality, human experience and mind? (Langer 1967: 74).

What does the term "feeling" mean for Langer? In her eyes, all organic beings on the one hand are pure matter, on the other hand lived experience. Biological processes are one aspect of an interwoven identity of physiological and intentional aspects. Life can not be different from matter. Thus, there has to be a kind of "forgotten side" of the material setting: Feeling is the manifestation of the biological theatre in a special perspective. "What is felt is a process, perhaps a large complex of processes, within the organism" (Langer 1967: 21).

But who feels? Langer tries to overcome the problem with the term "phase". "Being felt" is a phase of biological processes. "A phase is a mode of appearances, and not an added factor", she says, not a "product of neural impulses, but [...] an aspect of their occurence" (Langer 1967: 30). Like the red glowing of a heated metal is not external to it, but an inevitable aspect of its energy-rich state, feeling (to the "inside") and expressivity (to the "outside") are new phases of the living. The semiotic aspect is an emergent property of complex autopoietic systems. Being felt is a phase in which only organic systems appear. It is a shift to an emergent property that has not been contained in the sum of the parts - "constituents of one kind, brought together in a special combination, may seem to produce a new ingredient which is, however, a phase of their own occurrence" (Langer 1967: 21).

Unlike Jonas, who is focusing on the structuring function of feeling in perception of the world, Langer concentrates deeper on its 
particular structure, once it has emerged from the movements of organic acts. Feeling turns those processes into experience which are functioning "inside". Feeling displays the meaning those processes have for the concrete realization of the living. What shape does it have? Langer speaks of

forms of growth and of attenuation, flowing and stowing, conflict and resolution, speed, arrest, terrific excitement, calm, or subtle activation and dreamy lapses. (Langer 1953: 27)

Feeling thus is mirroring what happens to the organism in its selfrealization. Feeling is the meaning which external influences and the biological reactions to them have. "All external stimuli, that have effects on an organism affect the matrix, i.e. the organism as a whole, and through it motivate reactions [...]" (Langer 1982: 90). In this view the living being is seen as a more or less autonomous centre reacting by its own laws. Langer herself expresses an affinity to the concepts of general systems theory (Lachmann 2000: 153). But she is going farther, as Jonas does: The living system - as Langer says: the matrix - becomes an active agent: "Every distinguishable change, therefore, arises out of the matrix, and emerges as an act of an agent, for such a vital matrix is an agent" (Langer 1967: 322).

Consequently, the model of organic causation for Langer is not linear, or mechanical. It is rather parallel to the teleological causality we have in Jonas. Langer prefers to view an external trigger as a "motivation" (Langer 1967: 283) acting on a subject rather than a stimulus inducing causally a response:

The only way an external influence can produce an act is to alter the organic situation that induces acts; and to do this it must strike in a phase of ongoing activity, in which it is immediately lost, replaced by a change of a phase in the activity. (Langer 1967: 283)

"Motivation" is a term also Buytendijk (1958: 28f) uses for the same reasons as Langer does. Buytendijk thereby comes close to Uexküll's biosemiotic insights. Indeed Langer even refines her view by discussing Uexkülls Umwelt-concept. She does so without touching explicitly semiotic grounds. But we can state that the intrinsic teleology of the self-realising organism we discussed above might be used as a common denominator to describe an organism in semiotic 


\section{Andreas Weber}

terms. This relation sees also Lachmann (2000: 154n9) who refers to Maturana.

Every organism for Langer is composed of acts: small, circular processes joining to larger tissues of organic events and hence forming the "matrix" of the living as a reflexive system of circular acts (Langer 1982: 90). Langer's theory of organic acts therefore is a process theory of the living, as observes Lachmann (2000: 157). But in Langer's view, rather than being a (metaphysical) character of cosmos, processual reality stems from the way living subjects bring forth their reality. Langer hence offers a biological application of Whitehead. It is the organism who realizes the primacy of form over matter. What Whitehead conceives of as a metaphysics is, seen through Langer, the shape which the world gains by and through our organic makeup.

The act-model allows to make an abstraction from the basic biological level. Langer is speaking of the dynamics of life more in general, probably due to her inspiration by Whitehead. In a way Langer occupies a middle position halfway between process thinking and Jonas' views. Langer explicitly rejects the cosmological optimism stemming from Jonas' belief that feeling accompanies every process in organism. She even criticizes him for designing a "biological cosmos". Her theory is more general but lacks the plausibility of a generic account of the semiotic nucleus from the lack of the living. But also in Langer's work we can find an approach to the phenomenon of meaning which is based on considerations about the genesis of values. Langer holds that organisms perceive the meaning of situations according to their physiological needs:

[...] the primary characteristics which animals see are values, and all the qualities of form, color, shape, sound, warmth, and even smell, by which we would naturally expect them to recognize things, enter into their perceptual acts only as [...] values for action. (Langer 1972: 55)

This view reminds of Jonas. But speaking about values, Langer first and foremost analyses Uexküll's Umweltlehre. For Langer, all organisms have to cope with the existential values of situations they encounter in their surrounding worlds. The values of those encounters depend on the organism's biological structure. Value is thus shared by all organic beings in a common conditio vitae (Weber 2001a). On the other hand, Langer is emphasizing the difference of the ambient 
worlds of different species. Value differs according to taxonomic and even individual particularities: according to a specific and unique Bauplan. Following the "mother-value" of all values, the drive to exist, existential values create a vast range of meaning and significance. Feeling translates the biological meaning of a value which has been encountered into a subjective perspective: The value of a situation becomes manifest as feeling: "More and more, then, behaviour - the acts of an organism as a whole in relation to extraorganic conditions - comes to be guided and developed by feeling" (Langer 1967: 425).

According to each kind of organism, particular classes of values are modified into qualia or even, in humans, into mental concepts. Categories arise from these particular classes of value. But value precedes modal discrimination: value lies before the splitting of our perception into colours, tones, smells or touches. All these senses might have an existential dimension lying deeper than their qualia. This is a view which might help explain synaesthesia: Different sensory modes mean the same on a basic level concerning survival. A sharp tone and a sharp knife might have a common effect on organic feeling. As studies show, animals and children categorize apparently far-lying objects according to value. E.g. a baby learning to speak may call the brush, the broom and the dog's fur alike, because it touches them with the same sensation (this is an observation I made with my son). Eleanor Rosch (1978) has done landmark studies on this topic, followed by many others (Varela et al. 1991). Natural categorization thus yields a kind of natural, or "primary" metaphor (see Lakoff, Johnson 1999: 56). Symbols act via these basic categorization: symbols enact identical values that have the same "import" as their referents, existing in reality.

Langer beliefs that the values which the human organism experiences viz. brings forth are reflected in art. All great art, as she likes to put it, is an approach to organic feeling. The significance of music, e.g., lies in its "vital import", in its relevance to the dynamism of subjective experience. Art for Langer always rests in contact with the organic base: "Art is the creation of forms symbolic of human feeling" (Langer 1953: 40). As the feeling of organic acts itself does, formal elements in a work of art show features as dynamism, swelling, rest, tension, peace. For Langer, these features have the same existential value as can be encountered in organic experience. 


\section{Andreas Weber}

In Langer's eyes, organic feeling becomes somewhat transparent in human expressivity. But the access we have to the biotic layer, to the origin of our values, is never a direct one. We cannot tell by introspection what feeling the signs is like. We have to make the detour via artistic expression and so we must to substitute an embodied experience by another. Because of its organic source, there may always be ambiguity in the symbolization of feeling. Because "vital import" is reaching far beyond conscious semioses, it might always contain the ambivalences and even contradictions of pure vital dynamism:

The same feeling may be an ingredient in sorrow and in the joys of love. A work of art expressing such an ambiguously associated effect will be called 'cheerful' by one interpreter and 'wistful' or even 'sad' by another. But what it conveys is really just one nameless passage of 'felt life', knowable through its incarnation in the art symbol even if the beholder has never felt it in his own flesh $[\ldots]$ Even the artist need not to have experienced in actual life every emotion he can express. It may be through manipulation of his created elements that he discovers new possibilities of feeling, strange moods, perhaps greater concentrations of passion than his own temperament could ever produce, or than his fortunes have yet called forth. (Langer 1953: 374)

Due to its origin in value, and its intermodal nature feeling is projected in art as a quality, and not as a mental concept. Works of art exhibit the morphology of feeling, not by resting on conventional iconography, but by what Langer calls "living" or significant form-a form that does not convey a content but has an effect by transporting a certain value:

There is a kind of quality that different colours, or even a tonal form and a visual one, may have in common; even events may have the same quality, say of mystery, of portentousness, of breeziness; and a word like 'breeziness' bespeaks the qualitative similarity of some moods and some weathers. Homer refers to the 'wine-dark-sea', although Greek wine is red, and the Mediterranean is as blue as any other sea water. But the translucent blue in the curve of a wave and the glowing red in a cup of wine have a common quality [...] This quality is the projected feeling. (Langer 1967: 106)

For Langer significant form is an articulate expression of feeling. By reflecting the "verbally ineffable and therefore unknown forms of sentience" (Langer 1953: 39) the symbolization of feeling is a crucial factor of culture as the self-understanding of man. Via symbols felt 
organic experience can become accessible for others. Art is a means of intersubjectivity, a genuine path of interbeing. The gesture exists between the bodies as a gesture of living form between, inter the subjects. This might also contribute to explain furthermore the often stressed similarities between art and child's play. In both there are gestures, expressions of possible existence established in the virtual space beyond limited subjects. A theory of subjectivity would have to draw largely on this field (cf. the now classic critique by Helmut Schelsky 1958 on Uexküll).

These thoughts might help to see why Langer declares that "art is the objectification of feeling, and the subjectification of nature" (Langer 1953: 81). Artistic symbols express feeling in the same way as living form does. Their "felt tensions" can be apprehended only if their whole organic background is implied by their appearance. That is why for Langer every work of art has to seem 'organic' and 'living' to be expressive of feeling. (Langer 1967: 103). More recently, Gernot Böhme (1997) has coined the term Geste der Natürlichkeit, "gesture of naturalness".

Artistic form is acting as a sign on the same expressive level as organic form. That is what Langer means when she speaks of "living form". The gesture displayed by a work of art must convey the feeling which is provoked by the work's signifié when it is encountered in reality:

But just because the created appearance is all that has organic structure, a work shows us the appearance of life; and the semblance of functional unity is indispensable if the illusory tension pattern is to connote felt tensions, human experience (Langer 1953: 373). In creating an emotive symbol, or work of art, the creator does articulate a vital import which he could not imagine apart from its expression, and consequently cannot know before he expresses it. (Langer 1953: 389)

The relation between biochemical dynamics and organic feeling is of the same type as the relation between form and expression in a work of art. Both are expressive by means of their underlying vital dynamics. Expression hence is a symbol of its vital meaning, be it in a work of art or in a living body. As I have shown elsewhere (Weber 2001b), this relation equals the relation classically applied to the tension between body and soul. It is a symbolical relationship, 
symbolical in a strong sense: the symbol is not a convention but an expression of an underlying necessity. ${ }^{6}$

\section{The "conditio vitae": From vitality to expression}

These observations about the biological way of meaning creation might give some interesting hints for a semiotic theory of expressivity. Expressivity, as observed by Langer, the generation of meaning which refers to the inner perspective of an organism, could be an important feature of a theory of organism and of nature. Because expressivity is linked to form, like in works of art, this fact re-introduces an aesthetic aspect in the theory of organism. This formal, morphological or aesthetic aspect has not always been absent from biological thinking. Few examplary thinkers out of many more are Aristotle, Goethe and, more recently, Portmann.

Another most influential philosopher who saw a nexus between aesthetic thinking and the living organism was certainly Kant. In his famous reflections in the Critique of Judgement Kant tried to explain why a transcendental subject is capable of certain judgements about empirical objects in the world. Two circumstances were equally enigmatic for Kant: the possibility of aesthetic judgements and the possibility of teleological judgements - whether an object is alive and which criteria have to be adopted for a definition of the living organism (Lenoir 1982: 29).

Kant never solved the enigma (even if it was him who had contributed to complicate it a lot). Kant finally postulated a "happy chance" to reconcile the (empirical) natural manifoldness and the (ideal) faculty of judgement (Kant, Critique of Judgement, p. xxxiv). ${ }^{7}$ A biosemiotic approach based on "vital import" might provide some more answers. In the living organism, form is correlated with identity,

${ }^{6}$ This interpretation bears some similarities with Theodor W. Adorno's theory of art and the relation to an aesthetics of nature he sees (Adorno 1973: 115f). Cf. also Dieter Henrich's (2001) work on "Art and Life", where he explains the import of art in a delicate analogy with the momentum of subjectivity, though in solidly keeping to a rational theory of (human) subjectivity.

${ }^{7}$ This is the point where Goethe disagreed: For him, man could intuitively see, or rather "feel" the underlying laws of vital form in natural things, making them symbolical for our own existence, and even beautiful. 
the struggle to keep up identity is mirrored in form and manifest in the subjective perspective of feeling. Lived or intrinsic teleology and aesthetics seem to come into a close junction that should merit further attention. Langer observes:

If it could be shown that the forms of reason, or 'laws of thought', are forms of perception exemplifying larger laws of vital process, the 'happy accident' of 'reasonable' forms in nature, that Kant regarded as the basis of aesthetic pleasure, would not look so arbitrary as it did to him. (Langer in Lachmann 2000: 135n25)

Rather, we can add now, these forms might be expressive of the conditio vitae underlying organic existence. Beauty in organism is not arbitrary, nor a mere "happy chance". It is a necessity.

\section{References}

Adorno, Theodor W. 1973. Ästhetische Theorie. Frankfurt am Main: Suhrkamp. Böhme, Gernot 1997. Die Geste der Natürlichkeit. In: Natürlich Natur. Über Natur im Zeitalter ihrer technischen Reproduzierbarkeit. Frankfurt am Main: Suhrkamp, 141-159.

Goldstein, Kurt 1933. Die ganzheitliche Betrachtung in der Medizin. In: Steinkopf, Th. (ed.), Einheitsbestrebungen in der Medizin. Dresden.

- 1934. Der Organismus: Einführung in die Biologie unter besonderer Berücksichtigung der Erfahrungen am kranken Menschen. Den Haag: Martinus Nijhoff.

Goodwin, Brian 1997. Der Leopard, der seine Flecken verliert: Evolution und Komplexität. München: Piper.

Emmeche, Claus; Hoffmeyer, Jesper 1991. From language to nature: The semiotic metaphor in biology. Semiotica 84(1/2): 1-42.

Henrich, Dieter 2001. Versuch über Kunst und Leben. Subjektivität, Weltverstehen, Kunst. München: Hanser.

Hoffmeyer, Jesper 1997. Signs of Meaning in the Universe. Bloomington: Indiana University Press.

James, William 1890. The Principles of Psychology, Vol. 1.

Jonas, Hans 1953. Motility and emotion: An essay in philosophical biology. Proceedings of the Ninth International Congress of Philosophy 7: 117-122.

- 1973. Organismus und Freiheit. Ansätze zu einer philosophischen Biologie. Göttingen: Vandenhoeck und Ruprecht.

- 1992. Philosophische Untersuchungen und metaphysische Vermutungen. Frankfurt am Main: Insel.

Kauffman, Stuart 1998. At Home in the Universe: The Search for Laws of Selforganization and Complexity. London: Penguin. 


\section{Andreas Weber}

Kull, Kalevi 1999. Biosemiotics in the twentieth century: A view from biology. Semiotica 127(1/4): 385-414.

- 2000. An introduction to phytosemiotics: Semiotic botany and vegetative sign systems. Sign Systems Studies 28: 326-350.

Lachmann, Robert 1999. Animal perception as value perception. In: Evolution and Cognition (New Series) 5: 189-198.

- 2000. Susanne K. Langer: Die lebendige Form menschlichen Fühlens und Verstehens. München: Fink.

Lakoff, John; Johnson, Mark 1999. Philosophy in the Flesh. New York: Basic Books.

Langer, Susanne K. 1953. Feeling and Form. New York: Scribner's.

- 1967-1982. Mind: An Essay on Human Feeling. 3 volumes. Baltimore: Johns Hopkins University Press.

- 1979. Philosophie auf neuem Wege. Mittenwald: Mäander Kunstverlag.

Lenoir, Timothy 1982. The Strategy of Life: Teleology and Mechanics in 19th Century German Biology. (Studies in the history of modern science 13.) Dordrecht: Reidel.

Maturana, Humberto R.; Varela, Francisco J. 1980. Autopoiesis and Cognition: The Realization of the Living. Boston: D. Reidel.

Plessner, H. 1928. Die Stufen des Organischen und der Mensch. 3tte Aufl. Berlin: De Gruyter.

Portmann, Adolf 1948. Die Tiergestalt. Zürich: Rhein-Verlag.

- 1960. Neue Wege der Biologie. München: Piper.

- 1996. L'Autoprésentation, motif de l'élaboration des formes vivantes. Études Phénoménologiques 12(23/24): 131-164.

Rosch, Eleanor 1978. Principles of categorization. In: Rosch, E.; Lloyd, B. B. (eds.), Cognition and Categorization. New Jersey: Hillsdale.

Schelsky, Helmut 1950. Zum Begriff der tierischen Subjektivität. Studium Generale 2/3: 102-116.

Sebeok, T. A. 1976. The Sign and its Masters. Lanham: University Press of America.

Shelley, Clark 1998. Consciousness, symbols and aesthetics: A just-so story and its implications in Susanne Langer's 'Mind: An Essay on Human Feeling'. Philosophical Psychology 11: 45-66.

Uexküll, Jakob von 1973. Theoretische Biologie. Frankfurt am Main: Suhrkamp.

- 1980. Kompositionslehre der Natur. Uexküll, Thure von (ed.). Frankfurt am Main: Ullstein Verlag.

Varela, Francisco J. 1991. Organism: A meshwork of selfless selves. In: Tauber, A. I. (ed.), Organism and the Origins of Self. Dordrecht: Kluwer.

- 1997. Patterns of life: Intertwining identity and cognition. Brain and Cognition 34: 72-87.

Varela, Francisco J.; Thompson, Evan; Rosch, Eleanor 1991. The Embodied Mind: Cognitive Science and Human Experience. Cambridge: MIT Press.

Weber, Andreas 2001a. Cognition as expression: The autopoietic foundations of an aesthetic theory of nature. Sign Systems Studies 29(1): 153-168. 
- 2001b. Turning the inside out: Natural forms as expression of intentionality. Proceedings of the Finnish Semiotic Society (in print).

Weber, Andreas; Varela, Francisco J. 2002. Life after Kant: Natural purposes and the autopoietic foundations of biological individuality. Phenomenology and the Cognitive Sciences (in print).

\section{“Чувствуя" знаки: природа значения в биологической философии Сюзанны К. Лангер и Ганса Йонаса}

Статья рассматривает семиотический подход к организму в работах двух протобиосемиотических мыслителей. Оба автора развивают концепции, которые стали центральными в современной биосемиотике: организм как субъект, реализация живого как закрытая циркулярная “самость", концепция ценности, а у Лангер - и понятие символа. Лангер развивает теорию культурного символизма, исходя из организма как самореализующейся системы, которая создает как значение так и ценность. Данная статья сосредотачивает внимание главным образом на явлении, которое оба автора называли "чувство" (feeling). Они описывают "чувство" как основывающуюся на ценности перспективу, которая создается активным "самоинтересом" в органической системе. Результаты Йонаса и Лангер показывают формирование полюса субъекта или биосемиотического агента точнее, чем, например, у Юкскюлля. Их идеи можно связать и с “автопойезисом" (телесное узнавание или энактивизм) позднего Франциско Варелы. Синтез этих разных позиций может привести к пониманию того, каким образом символические выражения вырастают из биологических условий жизни.

\section{“Tundes” märke: tähenduse päritolu Susanne K. Langeri ja Hans Jonase bioloogilises filosoofias}

Käesolev artikkel vaatleb semiootilist organismikäsitlust kahe eel-biosemiootilise mõtleja - Susanne K. Langeri ja Hans Jonase - töödes. Mõlemad autorid arendavad kontseptsioone, mis on praeguses biosemiootikas saanud keskseiks: organism kui subjekt, elusa realisatsioon kui suletud tsirkulaarne "ise", väärtuskontseptsioon ja Langeri puhul ka sümboli mõiste. Langer arendab kultuurilise sümbolismi teooriat, lähtudes organismist kui ennast realiseerivast süsteemist, mis loob nii tähenduse kui väärtuse. Käesolev artikkel puudutab peamiselt nähtust, mida mõlemad autorid on nimetanud "tundeks". Nad kirjeldavad "tunnet" kui väärtusest lähtuvat perspektiivi, mille 


\section{Andreas Weber}

loob aktiivne enese huvi orgaanilises süsteemis. Jonase ja Langeri tulemused näitavad subjekti pooluse ehk biosemiootilise toimuri kujunemist täpsemini kui näit. J. v. Uexküll seda tegi. Nende ideid võib seostada ka arusaamaga autopoeesisest hilise Francisco Varela mõttes ('kehastunud äratundmine' või 'enaktivism'). Sääraste arusaamade süntees võib viia mõistmiseni, kuidas sümbolilised väljendused pärinevad elu bioloogilistest tingimustest. 